\title{
ICELANDIC ARTISTS IN THE NETWORK of THE EUROPEAN AVANT-GARDE - THE CASES OF Jón STEFÁNSSON AND FinNuR JóNSSON
}

\author{
Hubert van den Berg and Benedikt Hjartarson
}

Locating the centre(s) of an Icelandic avant-garde in the early twentieth century century is not an easy endeavour. As the careers of the visual artists Jón Stefánsson and Finnur Jónsson demonstrate, the roots of the Icelandic avant-garde are easier to trace to Dresden, Berlin, Paris and Copenhagen than to Reykjavík, where an absence of avant-garde activity characterised the art scene at that time. In a country where the first art exhibition was held in 1900, society had literally only just begun to offer possibilities for its few artists and writers to practise at a professional level. In contrast to most European countries, Iceland's lack of a tradition in the visual arts meant that at the beginning of the twentieth century its emergent artists were engaged in the very founding of a culture, rather than in rebelling against an existing one. Yet, this articulation of a tradition of Icelandic painting did not exclude the possibility of looking toward the European isms as points of orientation, as the cultural debates of the period bear witness to. However, the new aesthetic activities were usually not embraced wholeheartedly, but rather appropriated through a critical synthesis. Icelandic interest in the avant-garde focused on its aesthetic methods and techniques rather than its modes of aesthetic activism. Halldór Laxness' retrospective remarks on his early "surrealist" poetry provide a characteristic example of the dominant view of the vanguard artistic/literary movements and collective aesthetic programmes of the period. He claims that surrealism 
"in its purest form was [...] a kind of spiritus concentratus" which could not be consumed "unmixed" but had become "such an important element and vital condition of modern literature that those authors and poets of our generation, who did not learn from everything it offered as it appeared, could be declared dead" (1949: 142). This view prevailed until at least the early 1950s, as can be seen from a text by Sigfús Daðason from 1952. In "Til varnar skáldskapnum" (In Defence of Poetry), one of the first Icelandic attempts to elaborate a new poetics based in part on the literary avant-garde (more precisely, the surrealist poetry of Paul Éluard), the poet declares: "Surrealism in the strongest sense is in fact dead [...] but in another sense it continues to live, just like expressionism, naturalism, realism, romanticism, which have all become an element in the literature and culture of the world. Isms hardly seem to present a danger to Icelandic culture and in fact I believe it is a great benefit that it has been so reluctant to form schools" (Daðason 1952: 288-9).

Due to Iceland's small and (in comparison to many other European countries) underdeveloped aesthetic field, as well as its prevailing critical response to the isms, studying, dwelling and working abroad gave Icelandic artists otherwise unavailable opportunities to gather knowledge of new aesthetic trends and to work in a more progressive cultural environment. This not only applies to visual artists, who later became directly linked to avant-garde movements in Denmark, Germany and France, but also to Icelandic authors who were trying to establish themselves as professional authors. Faced with the limited possibilities in their home country, many authors who came to play important roles in the emergence of modern Icelandic literature in the first decades of the twentieth century chose to leave their home country and embark upon professional careers in a foreign language. The best known case is the group of Icelandic authors in Denmark who chose to write their texts in Danish, among them Jóhann Sigurjónsson, Gunnar Gunnarsson, Guðmundur Kamban and (for a short period) Halldór Laxness. The growth of Danish nationalism and an increasing interest in Icelandic culture as the cradle of all things Nordic turned out to be beneficial for the reception of their work and led to successful careers for a period of time (see Jóhannsson, 2001). Other authors chose to write in Norwegian or even German, as in the case of Kristmann Guðmundsson and the poet Jóhann Jónsson. ${ }^{0}$ The role of Copenhagen as the cultural - and, 
until 1918, political - capital of Iceland is also apparent in the context of the visual arts. Since Iceland had no art academy or educational possibilities for visual artists, most Icelandic artists went to Copenhagen. Some of them stayed on in Copenhagen after completing their studies, others used the city as a gateway to the cultural centres of Europe. Copenhagen offered Icelandic artists both formal education and exposure to the newest currents originating from cities such as Berlin and Paris. For some Icelandic artists Copenhagen provided an entrance into the transnational network of the avant-garde, initially as passive observers and later as active participants. Among the Icelandic artists who participated in the avant-garde network in the first quarter of the twentieth century, Jón Stefánsson and Finnur Jónsson are the most interesting: Stefánsson for his turn to Parisian fauvism in the first decade of the century; Jónsson for his participation in Der Sturm-related activities in Dresden and Berlin. The careers of these two artists can, moreover, be seen as characteristic of the Nordic avant-garde's turn from early expressionism (and cubism) in the first two decades of the twentieth century toward a more radical, Berlin-based notion of constructivism in the 1920s. Although more pronounced in Jónsson's case, the early work of both artists is characterised by a bold experimentalism rarely found in that of native contemporaries who had stayed in Iceland, and even in the work of those who chose to stay in Copenhagen and were exposed to the new "experimental" currents that had filtered through to the Danish art scene. Stefánsson's and Jónsson's links with avant-garde groups and movements in Berlin, Dresden, Paris, and Copenhagen enabled them to engage in a productive dialogue with the new art that would have been impossible within the Icelandic art scene.

\section{Jón Stefánsson: From Reykjavík to Copenhagen and Paris}

Finnur Jónsson's involvement with Der Sturm, one of the key vanguard organisations of the 1910s and 1920s, marks him out as the first Icelandic artist to participate in what is termed, according to Peter Bürger, the "historical avant-garde". Jón Stefánsson, on the other hand, was probably the first Icelandic artist to participate in the historical network of isms we now tend to call 'avant-garde', albeit on the periphery of French fauvism. With Matisse and Dérain as their main protagonists, Les fauves were the Parisian art sensation 
between 1905 and 1910 (although soon to be overtaken by cubism). News of their existence soon spread all over Europe, where they were noticed by other innovation-minded artists, not only in the cultural centres of countries like Germany - as in the case of the Neue Sezession, Die Brücke and Der blaue Reiter - but also in Scandinavia. In this period, Paris and Berlin served as the 'secret capitals' of modern Nordic art with an international ambition. In Paris, artists met each other and received news about the newest aesthetic trends. Stefánsson's career can be seen as a characteristic case in this context. Born in 1881, Stefánsson later took up painting (in Copenhagen) as a member of what would become - from a German perspective - the 'expressionist generation'. Stefánsson's formative training in the Danish capital took place at Christian Zahrtmann's art school alongside Michael Anker, one of the Skagen painters. Thus, his point of departure may be described as lying between naturalism and impressionism.

At Zahrtmann's school, where he studied from 1905 until 1908, Stefánsson became acquainted with other Nordic artists, including the Dane Harald Giersing and the Norwegian Henrik Sørensen. When Stefánsson travelled to Lillehammer in Norway with Sørensen in 1908 in order to paint, he made the acquaintance of another Norwegian, Jean Heiberg, who introduced them to the work of Matisse. As a direct consequence of this encounter, Stefánsson and Sørensen travelled on to Paris to continue their studies at the art school founded and directed by Matisse. In fact, they were part of a considerable number of young Nordic artists who journeyed to Paris in search of fauvist inspiration. One could say that Stefánsson entered the European avant-garde at this point, albeit more as a spectator than as a participant. Stefánsson destroyed almost all of his early work, including his output from his years at the Matisse school, and he never exhibited any of this work in Paris, Copenhagen or elsewhere. This naturally complicates attempts to form a clear view of his early career. It has been argued that three surviving paintings date from this early period from 1908 to 1916 (see Ingólfsson, 1993). These paintings display a close proximity to the work of Matisse and his Nordic pupils, as well as an interest in occult symbolism rarely found in his later work. If the dating of these paintings is correct, Stefánsson's style during these years evolved in a post-impressionist, fauvist direction. Stefánsson's first participation in a collective exhi- 
bition did not come until 1919, at the Kunstnernes Efteraarsudstilling (The Artists' Autumn Exhibition) in Den frie Udstillingsbygning (The Independent Exhibition Building) in Copenhagen.

Stefánsson left Paris in 1911, shortly before the closure of the Matisse art school, and returned to Iceland. In 1913 he moved back to Copenhagen, where he continued to work in the 'new' Parisian style - a style that (in Paris at least) had now been superseded by a development towards increased abstraction, as in cubism and futurism. In Denmark, but also for example in the Netherlands, Parisian developments were not copied immediately. In some respects the fauvist leap was revolutionary enough for the Nordic art community for its impact to persist longer than it did in Paris. So while Stefánsson's work was in no way cutting-edge compared to what was being produced contemporaneously in Paris or Berlin, it nevertheless belonged to the Danish fringe of the international avant-garde network. Stefánsson's place in the Danish avant-garde is indicated by his contributions to the Copenhagen-based publication Klingen (The Blade). Judging by the majority of its contributors and their contributions, Klingen was a predominantly modern or 'modernist' magazine, presenting, on the whole, rather moderate examples of the 'new art'. Yet the journal also contained quite radical contributions, from both foreign and 'local' artists, such as the poem "Berlin" by Emil Bønnelycke and an abstract work by the Norwegian Alf Rolfsen. The work by Stefánsson reproduced in Klingen can hardly be described as belonging to the more 'radical' works in the journal. For a proper understanding of Klingen, and of Stefánsson's contributions, it is important to note that the magazine is a quite typical product of the situation in the field of the 'new art' in Copenhagen during and after the World War I. Likewise, the mixed contents of Klingen can be seen as symptomatic of the general situation in the cultural field in Europe. Many modernist reviews, such as the Dutch Het Getij, provide similar cases, presenting almost identical mixtures of avant-garde or maybe modernist, but, nevertheless, rather conventional art and literature. A comparison of Klingen and Der Sturm reveals that the more traditional contributions of the two publications are far from dissimilar. Thus Stefánsson's contributions to Klingen appear less conservative than one might think, and it is certainly not a coincidence that his work was exhibited in 1920 in Georg Kleis' Copenhagen gallery, where a large Sturm-exhibition, discussed in Klingen, had 


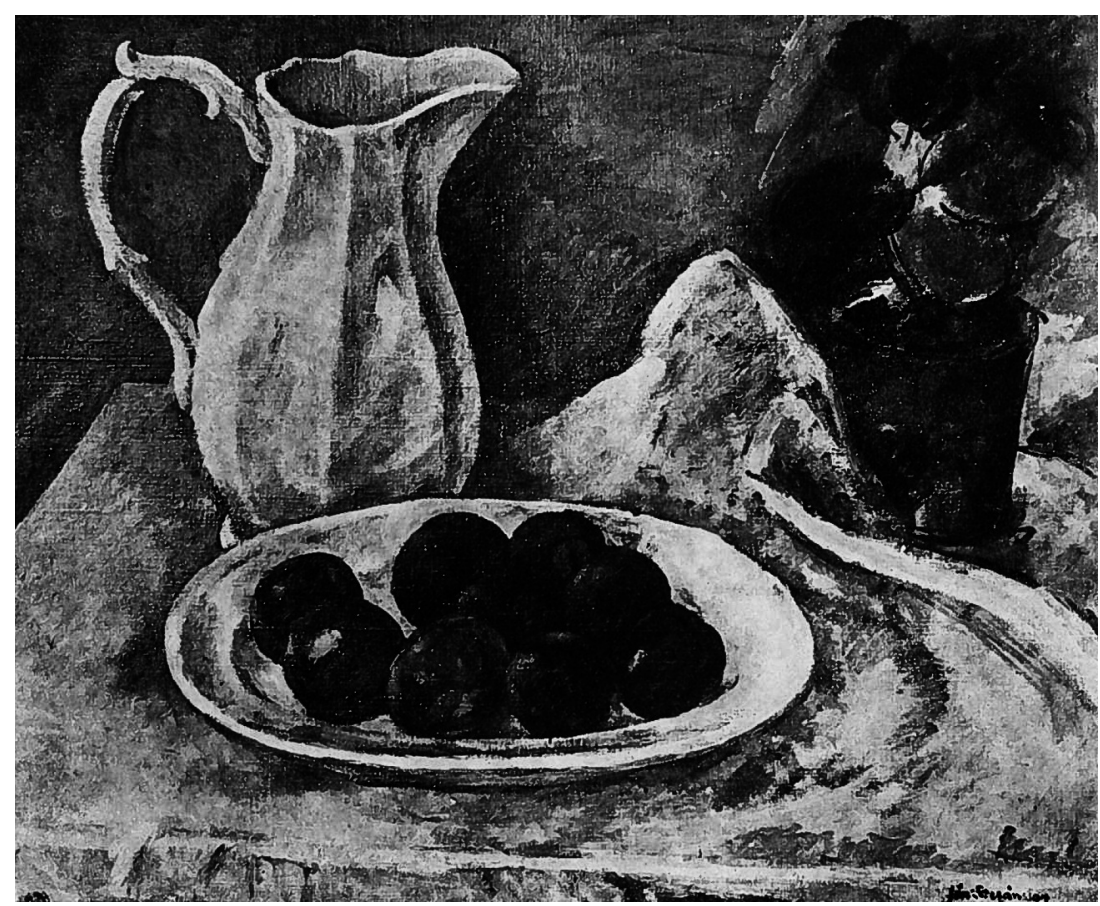

Illustration for Otto Gelsted's essay, "Jon Stefansson", in Klingen, Vol. 2. No. 61918 (unpaged).

taken place two years earlier. Stefánsson's work, however, was not shown in the context of Klingen or Der Sturm, but as part of a collective exhibition entitled "Fem islandske Malere" (Five Icelandic Painters), which gave a general survey of contemporary Icelandic art, including works by Ásgrímur Jónsson, Guðmundur Thorsteinsson (Muggur), Kristín Jónsdóttir and Pórarinn B. Porláksson. Although Stefánsson is described as the "only mature" Icelandic painter in a note on the exhibition published in Klingen ("Islandske Malerkunst" (Icelandic Painting), 1920), thus stressing the importance of the Danish background of his work, Klingen also has a reproduction of a doll made by Thorsteinsson, which in itself is just handicraft, but in the period a common artefact in a dadaist context.

Stefánsson's contributions to the Efteraarsudstilling, Klingen, and the Kleis gallery exhibition present the artist as an active participant 
in the Copenhagen avant-garde. They also mark the end of his involvement in the network of the avant-garde. Although Stefánsson lived in Copenhagen until 1924, his association with the avant-garde went into sharp decline following a return to Iceland in the summer of 1920, before the definitive break in 1924. Although his work was shown in Denmark on some later occasions, as well as at an exhibition of Icelandic art by the German Nordische Gesellschaft (Nordic Society) in 1928, ${ }^{1}$ Stefánsson's return to Iceland created a considerable geographical and communicative distance. The return to a more conservative artistic climate (in which 'fauvism', far from being regarded as not revolutionary enough, was in fact conceived as being too revolutionary) paralleled Stefánsson's move away from the avantgarde dimension of Matisse and fauvism, which also had a more moderate or 'classical' dimension. Stefánsson's work from the Copenhagen period bears unmistakable witness to the fact that he was influenced or inspired by Matisse and fauvism (as well as by its forerunner Cézanne). Thus he may be labelled (in contemporary terms) a fauvist - or, in German terms: an expressionist. Stefánsson's works were also referred to in the pages of Klingen as a prime example of 'expressionism' and its rupture with the painterly tradition of impressionism, as a text by Otto Gelsted from 1918 demonstrates (see also Uttenreitter, 1936). While Stefánsson may have handled colour and depicted people and objects in a fauvist manner, he did so without any of the wildness promoted by the movement. As a participant in the international avant-garde network, he remained rather on the outside, at least as seen from a French and German perspective. In this respect, Stefánsson's approach differs markedly from that of Finnur Jónsson. However, on closer inspection, parallels between their careers become apparent.

\section{Finnur Jónsson and Der Sturm}

Leaving aside his education and work as a goldsmith, ${ }^{2}$ the first port of call in Jónsson's artistic career was also Copenhagen. A student in the art school of Viggo Brandt, Jónsson was trained in the naturalist school of painting, his point of departure thus showing clear similarities to Stefánsson's career. This was basically the normal 'academic' start for the average avant-garde career in this period, no different from the start of Mondriaan, Malevich or Schwitters. 
Compared to Stefánsson, Jónsson's career is noteworthy due to the relative rapidity with which various developments superseded one another. Born in 1892, Jónsson was a decade younger than Stefánsson. He also started in Brandt's school in 1919, a little over a decade later than Stefánsson had started at Zahrtmann's school. The artistic climate in Copenhagen at the end of the First World War was different from that of the first decade of the twentieth century. The war had had a significant impact: connections with France were few, limited and hard to maintain, due to Denmark's geographic location on the Northern side of the German Empire.

As the case of Klingen indicates, France continued to provide a programmatic orientation for Nordic artists during the war. Likewise, German influence did not disappear. Although Germany, like France, had closed its borders to the neutral countries - Denmark, the Netherlands and Switzerland - Germany remained the easiest to reach. The inverse was also true, as art, art dealers and exhibitions from Germany could still pass the borders, albeit with some difficulty. As a result, and - it should be added - as a side-effect of Herwarth Walden's active collaboration with the German secret service (for whom he worked as an intelligence agent during the war), avantgarde art with a German provenance was regularly on show in Denmark and Sweden. In other words, as a result of the war, communication lines to Paris were redirected to Berlin. This, however, had little impact on the art on display: Walden and his Sturm gallery had a good number of examples of French fauvism and cubism in stock. Another consequence of the wartime border closures was that transport and communication lines - most notably, those from Scandinavia - ended in Denmark. As a result, Copenhagen obtained a special status within the Nordic art community during the war as a kind of surrogate for Paris and Berlin. The city's (temporary) status as a vibrant avant-garde centre might explain why Jónsson developed much more quickly in an avant-garde direction than Stefánsson. Like Stefánsson, Jónsson entered the avant-garde in a passive way. In 1920, he moved from Brandt's school to that of the Danish painter Olaf Rude, who had taken up cubism several years earlier and belonged to the circle around Klingen. So, whereas Stefánsson had to go to Paris to draw fauvist inspiration, Jónsson was able to stay in Copenhagen and learn the cubist idiom. Nevertheless, one year later he relocated to Berlin. As described above, the way to 


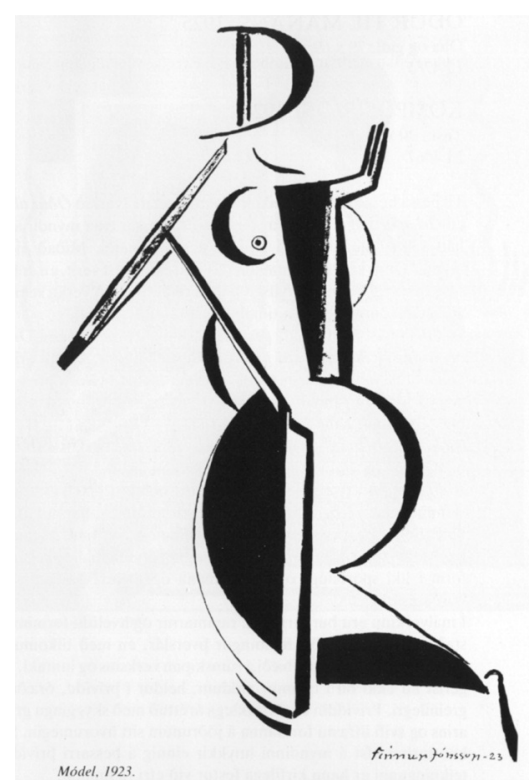

Finnur Jónsson, Módel (Model), $1923,47.5 \times 32.5 \mathrm{~cm}$, ink drawing. Listasafn Íslands (National Gallery of Iceland).

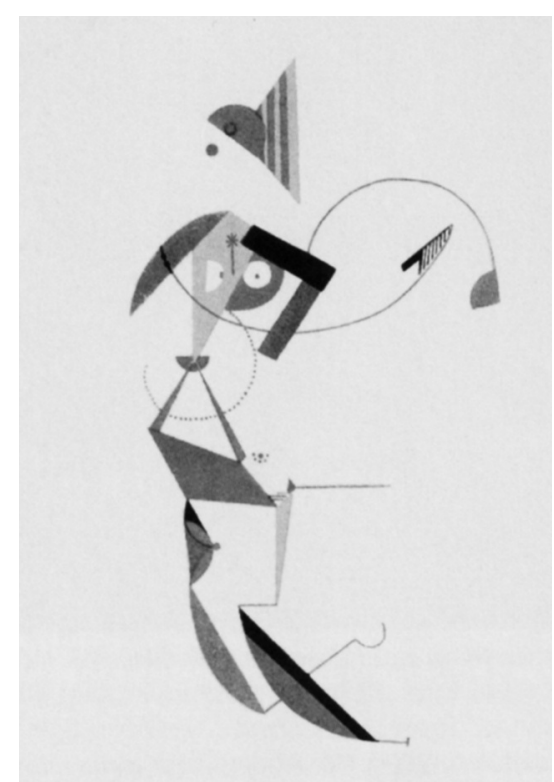

Lothar Schreyer, Die lüsterne Frau, $1922,39.8 \times 30 \mathrm{~cm}$, colour lithography on plane white cardboard, figurine for the marionette play Birth. Bauhaus-Archiv, Berlin.

Berlin was opened by the war. Whereas a journey to France had become more complicated, the borders to Germany had become easier to cross after the outbreak of the war. More importantly, Berlin (aside from its turbulent political and economic situation) offered artists something different than Paris, which came under the grip of dada in 1920-21. Berlin was dominated by 'expressionism' in the widest sense, with Der Sturm providing the main point of orientation: the art scene in the city was thus far more international than that of Paris. Furthermore, as mentioned, special ties existed between the Copenhagen art scene and Der Sturm. During the war Walden and his Swedish wife Nell Walden-Rosland were not only active in the artistic field. Beside the art enterprise Der Sturm, there was also the intelligence, news and propaganda agency Der Sturm, which op- 


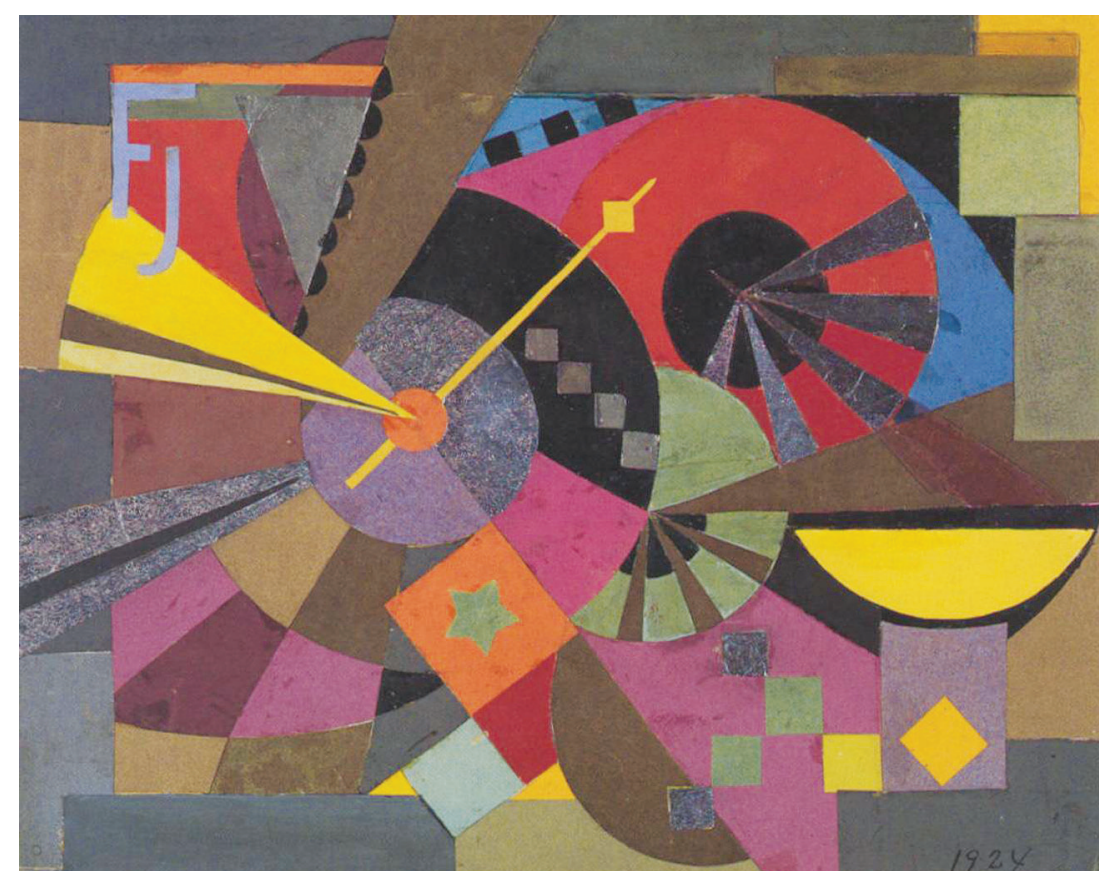

Finnur Jónsson, Sinfónía (Symphony), 1924, 20.8×25.6 cm, collage. Listasafn Íslands (National Gallery of Iceland).

erated notably in Denmark, Sweden and the Netherlands as a kind of private contractor for the German secret service. The Waldens travelled frequently to Copenhagen and Sweden, partly to continue their art business, partly to carry out their intelligence work (which gave them considerable freedom to travel and export art, e.g. for exhibitions).

In Berlin, Jónsson came into contact with Der Sturm and took lessons at the art school of Carl Hofer, an expressionist with classical leanings akin to Matisse. As such, Hofer was - even by Copenhagen standards - a rather conventional 'modern' artist, not unlike Stefánsson. Hofer's influence is apparent in Jónsson's work from this period. However, it seems that Hofer's approach did not satisfy Jónsson for long. Indeed, in comparison to the latest avant-garde developments of the time, such as the abstract work of Mondriaan and Malevich 
or Schwitters' first Merz works (the latter were shown in the Sturm gallery), Hofer's work is highly conventional. Judging by the subsequent work he undertook in Berlin, and later Dresden, Jónsson was attracted to the work of Schwitters and other artists from the Sturm stable who developed in abstract, constructivist directions in the years following the First World War. These artists, now lesserknown, included Oskar Fischer, Johannes Molzahn, Thomas Ring, Fritz Stuckenberg, Eduard Kesting, Vordemberge-Gildewart, Lajos Kassák and Lothar Schreyer. The affinities between the works of Jónsson and these artists are obvious. Although a more precise assessment of Jónsson's position in the Sturm circle has still to be made, it can be claimed with certainty that many elements in his work appear as visual quotes from the work of these artists.

Jónsson's decision to turn to Der Sturm was quite typical for a young, foreign avant-garde minded artist new to Berlin. Although Der Sturm was rapidly losing (or had already lost) its pivotal role in Germany's artistic field, its reputation abroad remained intact and almost all foreign artists visiting Berlin (for example from the Netherlands, Belgium, Bulgaria et cetera - i.e. from the European cultural provinces - but also Tristan Tzara and the dadaists from Paris, for example) went to Der Sturm. The reason was simple: in the previous decade, Der Sturm had been very active not only in the German Empire, but also abroad. Obviously attracted by the new developments represented both in the Sturm-journal and gallery, Jónsson remained in its inner circle. Jónsson did not stay in Berlin, but went to Dresden, where Oskar Kokoschka, a regular contributor and a close friend of Walden since the inception of Der Sturm, taught at the art academy. Dresden was also the place where the expressionist/constructivist painter and photographer Edmund Kesting led an art school named "Der Weg: Schule für Neue Kunst" (The Direction: School of New Art). Jónsson's decision to go to Der Weg may have been influenced by his contact with the Icelandic composer Emil Thoroddsen, who was studying at the school at this time. Der Weg was very close to Der Sturm; indeed, it can be seen to belong to the avant-garde network surrounding Der Sturm, given that Kesting was one of Walden's close associates in the 1920s. Interesting here is the similarity between a portrait of Walden by Kesting and a painting by Jónsson, which also resonates with other works by Stuckenberg and Schwitters. From his largely passive position on the fringe of the 
avant-garde network close to Der Sturm, Jónsson also established contacts with Schwitters and Moholy-Nagy. Jónsson's work increasingly developed in a constructivist direction, his constructivism remaining close to the artistic ideas propagated by Der Sturm - one main difference from Dutch and Russian constructivism being the fact that the aesthetics of Der Sturm was often not geometrical or not exclusively geometrical. It is interesting that not only does the biographical data situate Jónsson in the environs of the avant-garde community close to Der Sturm, but comparison of individual works also shows that the development of his art leads directly to this position.

It took Jónsson several years to step out of his more or less passive role in the Sturm community and into the role of an active participant in the avant-garde network. According to Jónsson's own account, or, more accurately, an amalgam of several different indications, in 1924, Oskar Kokoschka and Kurt Schwitters advised him to present his work to Walden in Berlin (see Pálmadóttir, 1992; Runólfsson, 1987). Upon arrival at Der Sturm, Jónsson (still by his own account) discovered that Kandinsky happened to be present. Both Kandinsky and Walden turned out to be very enthusiastic about his work and chose eight paintings, which were subsequently exhibited in the Sturm gallery in the summer of 1925 and afterwards included in a touring Sturm exhibition in North America. It is not unlikely that Kandinsky appreciated Jónsson's work. However, Kandinsky's relations with Walden were quite tense in the 1920s, so the chance that they would judge the work of another artist together seems unlikely. And Schwitters proposal to Jónsson that he should go to Berlin? It may not be unlikely that Schwitters asked Jónsson, 'Why don't you exhibit at Der Sturm?', but given that Berlin was only a few hours by train from Dresden, it seems far more probable that Kesting suggested Jónsson to Walden, who would then have invited Jónsson for a meeting. Walden, who was facing serious financial problems at this time, would have been glad of 'fresh blood'. This was as fortunate a situation as Jónsson could have imagined.

The Sturm enterprise's great financial trouble was due to a number of factors: the inflation; the trials of several artists, including Kandinsky and Chagall, who, as a result, were demanding payment; lastly, Walden's divorce from Nell Walden-Roslund, who had, in fact, been financing Der Sturm for some time. As part of the divorce 
arrangements, she received the private art collection, the 'Sammlung Walden', which had always made up an important component in Sturm exhibitions. Walden, by this time, had also developed something of a bad reputation within the German art community. He was suspected of financial misbehaviour and exploitation of artists represented by his gallery. These suspicions were exacerbated by his fierce, merciless and rather nefarious polemics against those whom he regarded either as irritating competition or as opposed to his aesthetic programme. Thus Walden turned his attention to emerging artists interested in any exhibition opportunity; not only those from Germany, but from other countries, too, where Der Sturm's reputation still endured. Thus Walden needed Jónsson, no less than Jónsson needed Der Sturm. As an emerging and relatively inexpensive artist, Jónsson probably had to pay for all exhibition costs, given that this was Walden's policy, even in the case of his star artist, Jacoba van Heemskerck.

This much is clear: during the period in question, Jónsson's work was listed in a commemorative Der Weg catalogue, as well as in two Sturm catalogues dated July and September 1925, not as one of the main artists of these exhibitions (who featured in the titles of the exhibitions), but as part of the so-called Gesamtschau, or 'collective section', a cross-section of works currently in the gallery's stock. This recognition of Jónsson's work by the Sturm network marks the end of the artist's involvement in both this network and the avant-garde in general, although he apparently had the intention of maintaining his activities as an avant-garde artist once he was back in Iceland as an exhibition at Café Rosenberg in Reykjavík in the winter of 1925, featuring abstract works, indicates. This not so grande finale has obvious parallels to Stefánsson's fleeting involvement with the Copenhagen avant-garde. Critical response to Jónsson's Icelandic exhibition was mixed. Several reviews were quite positive; however these were written by critics and artists close to Jónsson in some capacity. Valtýr Stefánsson's extremely negative review is notable. According to Jónsson, the circle of Icelandic artists in Copenhagen to whom the reviewer was connected had become hostile to Der Sturm and its associates after their fellow Icelander Jón Porleifsson's unsuccessful attempts to have his works exhibited in Walden's gallery (see Gottskálksdóttir, 1993: 93). Jónsson's decision to stop painting in a Sturm-like, constructivist way has often been explained as a re- 
sponse to the negative reviews of the exhibition. A closer look reveals, however, the inadequacy of this explanation.

Having apparently stopped working in his avant-garde idiom, Jónsson took up occasional work as a goldsmith before returning to figurative painting. Although Jónsson created some abstract work in later years, his departure from the avant-garde network coincided with the end of his exploration of avant-garde aesthetics, as had been the case with Stefánsson. An important question arises: Which came first - the turn away from avant-garde aesthetics or the break with the avant-garde network? An obvious explanation might be that by returning to Iceland and its 'provincial' art scene, Jónsson - intentionally or otherwise - severed his connection to the European avantgarde network, thus excluding the possibility of sustaining an active dialogue with like-minded artists abroad. One might argue that Jónsson had to adapt himself to the taste of the province, where only very moderate and diluted avant-garde elements resonating with the provincial tradition of naïve painting (itself a source of inspiration for the figurative avant-garde) were accepted as supplements to figurative work. Painting styles that diverged from these pictorial conventions in a radical manner, like abstract constructivism, were thus not an option. However, another important factor must be acknowledged: In most parts of Europe, the heyday of the avant-garde had ended by the mid-1920s. Admittedly, constructivism endured, albeit in a more institutionalised form lacking its previous revolutionary impetus (the Bauhaus, for example, became the state-funded Staatliches Bauhaus) and, in France and Belgium, surrealism was only just beginning to articulate itself clearly (Breton's first surrealist manifesto was published in late 1924). On the whole, however, the majority of avant-garde initiatives, projects and journals that had emerged in the 1910s or early 1920s collapsed, evaporated or simply stopped around 1925 or shortly thereafter. In the Dutch context, for example, a number of artists continued their avant-garde activity (e.g. Mondriaan and Van Doesburg, still living in Paris). De Stijl continued until 1928, albeit no longer in its initial weekly edition, while a number of other notable constructivist journals appeared alongside it in the late 1920s. Examples of these include the somewhat more voluminous internationale revue i10, and - in terms of format and distribution - the smaller reviews De Driehoek, Het Woord and The Next Call. However, most artists and writers who 
had been involved in the avant-garde in the 1910s and early 1920s ceased to be so and returned to more conventional forms, a process that was aptly accompanied by a turn from the abstract to the figurative. The same tendency can be observed in most other European countries. It can thus be argued that Jónsson's departure from avantgarde aesthetics was not entirely the result of his return to the isolated Icelandic 'province'. On the contrary: Jónsson's break with (constructivist) avant-gardism was no isolated case; rather, he was only one of many artists and writers who made the same decision. At the centre of the constructivist avant-garde around 1925, initially on the peripheries and later in the inner circle of Der Sturm, Jónsson may well have been aware of the growing doubts, changes and shifts that would lead to the demise of so many avant-garde initiatives during this period. This atmosphere would certainly have suggested a need for new directions, even if they resembled old ones.

\section{Finnur Jónsson's Exhibition in Reykjavík 1925 and the Debate Surrounding Der Sturm}

As the preceding survey of Stefánsson's and Jónsson's careers shows, their early development took place within the context of the continental European avant-garde. From an Icelandic perspective, their early work has traditionally been seen as a rather isolated breakthrough of avant-garde art in the early twentieth-century, as the contribution of two young artists who absorbed the latest currents from the continental art scene, anticipating new aesthetic paradigms which only gained acceptance many decades later in the Icelandic cultural field. It was certainly not accidental that neither Stefánsson nor Jónsson invested much effort in positioning their early avant-garde work within the Icelandic art scene, at least not in the 1910s and 1920s. Any attempt to do so would have been a waste of energy, as the Icelandic debate on Jónsson showed, which followed the single exhibition of his continental European avant-garde oeuvre in Reykjavík in 1925.

Jónsson's exhibition in November 1925 generated a heated debate among the artists of Reykjavík which affords a view of the ideological issues at stake in the Icelandic response to the avant-garde. This debate can be seen as the manifestation of extensive hegemonial conflicts and reveals the sway which nationalist ideologies held over Iceland's cultural life in the mid 1920s. Although the critics' views of 
Jónsson's work differed profoundly, almost all expressed a nationalist attitude aimed at forging a healthy and powerful national culture in compliance with the natural disposition of the Icelandic people. The press-based debate, which mainly revolved around Der Sturm, actually predated Jónsson's exhibition. On 22 July, Valtýr Stefánsson, editor of Morgunblaðið (The Morning Post), published an anonymous notice reporting Jónsson's return to his homeland after far too long a stay in Germany. The editor acknowledged Jónsson's affiliation with Der Sturm, and pointed out the gallery's notorious policy of not accepting any work that was not in "the spirit of modern art movements" (Blaðagreinar (1983): 48). Four days later, Jónsson responded to this notice, thus opening the public debate. Jónsson stressed the international character of Der Sturm, explained its broad conception of "expressionism" in terms of "new art", and referred to the work of "mature artists" such as Chagall, Kokoschka, Kandinsky, Archipenko and Picasso. The editor Stefánsson responded by pointing out Walden's dogmatism and polemical style (which had obviously reached the Northern peripheries). More interesting than the debate on the nature of expressionism, however, is Valtýr Stefánsson's description of Jónsson's November exhibition. The critic, in a somewhat ironic gesture, predicted a more positive future career for Jónsson, provided that "he doesn't immerse himself too deeply into the German aping of French art" (Blaðagreinar 1983: 51). These remarks, which reveal a clear alternative opinion about the model on which the Icelandic art of the future should be based, echo debates that had shaped the cultural field in Copenhagen since the mid 1910s, when anti-German resentment and pro-French attitudes were on the rise (see Jelsbak 2005). Stefánsson's comment regarding the "German aping of French art" has striking similarities to earlier descriptions of work by Danish "expressionists" as "poor imitations of German imitations", to quote Andreas Vinding in a 1918 article for Politiken (quoted in Aagesen 2002: 168).

The nationalist perspective articulated in Valtýr Stefánsson's review was given a more positive spin in Björn Björnsson's report on Jónsson's exhibition. Writing in Visiri, Björnsson warned against narrow-mindedness and pointed out the genuine Nordic character of even the abstract paintings. Whether they celebrated or dismissed Jónsson's exhibition, all responses sprang from the nationalist perspective pervading the young Icelandic nation state. Indeed, this 
point of view was not confined to the reviews published in the two right-wing newspapers quoted above, but also appeared in left-wing newspapers. The most curious example is Emil Thoroddsen's review, in which the notion of 'imitation' also played a central role. In a rhetoric characteristic of the German Jugendbewegung, which Thoroddsen had probably become familiar with during his studies in Dresden, the author praised the youthful energy of Jónsson's art, describing it as the manifestation of a genuine Germanic character:

Isn't Icelandic art for the most part a bad imitation of bad Danish painters who themselves are not very original and hasn't art thus arrived in Iceland in outworn copies? I believe that those people who have been sucking skimmed milk from the baby bottle of the artistclique in Copenhagen, which is nurtured by an outmoded 'formalism' and misunderstood French watchwords, don't like the fact that a Germanic flavour appears in some of Finnur Jónsson's paintings (Blaðagreinar 1983: 50).

The path chosen by Jónsson after the exhibition may reveal that he was not as strongly drawn to the völkisch cult of the Germanic as Thoroddsen, his former fellow student at Der Weg. The increasingly chauvinistic rhetoric radiating from all sides in the debate surrounding Jónsson's exhibition may shed additional light on the artist's shift in idiom. Jónsson's insistence on the international character of Der Sturm and his unwillingness to follow Thoroddsen's line may indicate that Jónsson did not feel at ease in an increasingly hostile cultural field pervaded by the idea of national identity and thus consciously sought to position himself between emerging political extremes. Indeed, Jónsson's contributions to the debate represent the only voice not driven by nationalist rhetoric. If the debate generated by the Café Rosenberg exhibition was indeed instrumental in the shift in Jónsson's career, his choice of a different path may not only be seen as a reaction against his critics but also as a defence against his devotees. 


\section{NOTES}

${ }^{0}$ Jónsson was writing in Icelandic and German in Leipzig during the 1920s.

${ }^{1}$ The Nordische Gesellschaft exhibition also featured work by Finnur Jónsson, among others. The curatorial focus was not the avant-garde; rather it treated the works as objects of a kind of contemporary ethnographic interest, related to the predominant völkisch (folksy?) ideology of the period (see Gretor, 1928).

${ }^{2}$ Jónsson trained under, among others, Baldvin Björnsson, who was the first Icelandic artist to make attempts at abstract painting during his stay in Berlin in the 1910s. 
Icelandic Artists in the Network of the European Avant-Garde 247

WORKS CITED

Aagesen, Dorthe. 2002. "The Avant-Garde Takes Copenhagen”. The Avant-garde in Danish and European Art 1909-1919. Edited by D. Aagesen. Copenhagen: Statens Museum for Kunst, 152-171.

Blaðagreinar 1921-1929. 1983. Frank Ponzi (ed.). Finnur Jónsson. Íslenskur brautryðjandi. Reykjavík: Almenna bókafélagið, 48-51.

Daðason, Sigfús. 1952. "Til varnar skáldskapnum”. Tímarit Máls og menningar, 3: 266-290.

Gelsted, Otto. 1918. Jon Stefansson. Klingen, 6: [no page numbers]

Gottskálksdóttir, Júlíana. 1993. "Tilraunin ótímabæra. Um abstraktmyndir Finns Jónssonar og viðbrögð við peim”. Árbók Listasafns Íslands 1990-1992. Reykjavík: Listasafn Íslands, 74-103.

Gretor, Georg. 1928. Islands Kultur und seine junge Malerei. Jena: Diederichs.

Ingólfsson, Aðalsteinn. 1993. "Jón Stefánsson, Grünewald, Matisse og Picasso. Hugleiðingar um prjár myndir”. Árbók Listasafns Íslands 1990-1992. Reykjavík: Listasafn Íslands: 12-29.

Islandsk Malerkunst. 1920. Klingen, 6-7: [no page numbers]

Jelsbak, Torben. 2005. Ekspressionisme. Modernismens formelle gennembrud i dansk malerkunst og poesi. Hellerup: Forlaget Spring.

Jóhannsson, Jón Yngvi. 2001. "Jøklens Storm svalede den kulturtrætte Danmarks Pande”. Um fyrstu viðtökur dansk-íslenskra bókmennta í Danmörku. Skírnir, 175 (vor): 33-66.

Kvaran, Ólafur. 1989. "Jón Stefánsson. Sensations and Classical Harmony”. Jón Stefánsson 1881-1962. Edited by Karla Kristjánsdóttir. Reykjavík: Listasafn Íslands, 41-55.

—. 2006. Jón Stefánsson. "Nemandi Matisse og klassísk myndhefð”. Frelsun litarins / Regard Fauve. Ed. by Ó. Kvaran. Reykjavík: Listasafn Íslands: 41-42.

Laxness, Halldór. 1949. Kvøðakver. Reykjavík: Vaka-Helgafell.

Pálmadóttir, Elín. 1992. "Vor hinnar ungu listar. Spjallað við Finn Jónsson um listir í Evrópu á öðrum og priðja áratugnum”. Finnur Jónsson i Listasafni Íslands. Ed. by Karla Kristjánsdóttir. Reykjavík: Listasafn Íslands, 49-53.

Ponzi, Frank. 1983. "Artist Before His Time”. Finnur Jónsson. Íslenskur brautrydjandi. Edited by Frank Ponzi. Reykjavík: Almenna bókafélagið, 53-60.

Runólfsson, Halldór Björn. 1987. "Concrete Art in Iceland”. Konkret i Norden. Pohjoinen konkretismi. Norran konkretlist. Nordic Concrete Art. 1907-1960. Helsinki: Nordic Arts Centre,160-163,

Stefánsson, Jón. 1989. “Nokkur orð um myndlist”. Jón Stefánsson 1881-1962. Edited by Karla Kristjánsdóttir. Reykjavík: Listasafn Íslands, 1989, 79-85.

Uttenreitter, Paul. 1936. Maleren Jón Stefánsson. Copenhagen: Rasmus Naver, 1936. 